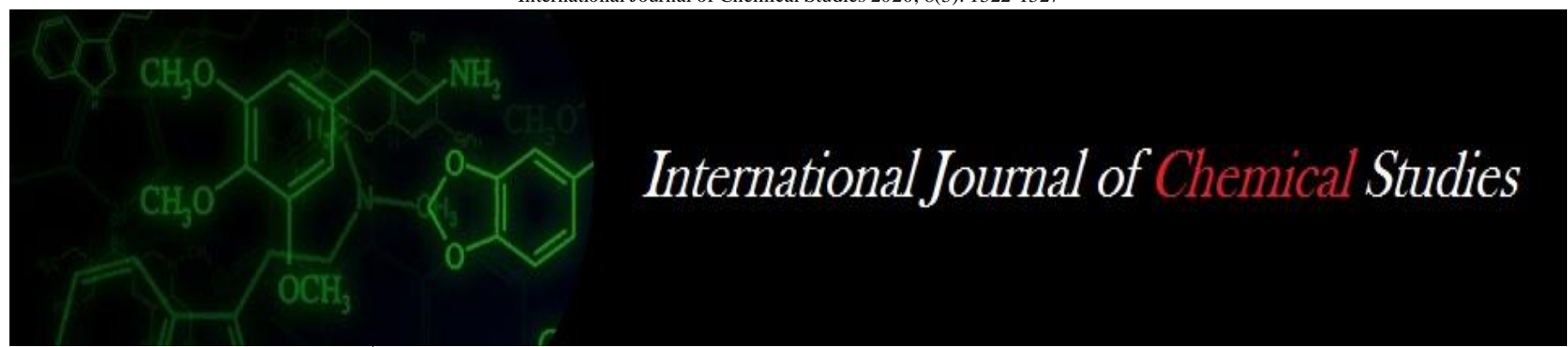

P-ISSN: 2349-8528

E-ISSN: 2321-4902

www.chemijournal.com

IJCS 2020; 8(3): 1322-1327

(C) 2020 IJCS

Received: $12-03-2020$

Accepted: 14-04-2020

Suyog Aware

Dept. of Biochemistry and

Molecular Biology, K. K. Wagh

College of Agricultural

Biotechnology, Nashik,

Maharashtra, India

Shubham Malode

Dept. of Biochemistry and

Molecular Biology, K. K. Wagh

College of Agricultural

Biotechnology, Nashik,

Maharashtra, India

Bhushan Mahure

Dept. of Biochemistry and Molecular Biology, K. K. Wagh

College of Agricultural

Biotechnology, Nashik,

Maharashtra, India

Swapnil Pawar

Dept. of Plant Biotechnology, K.

K. Wagh College of Agricultural

Biotechnology, Nashik,

Maharashtra, India

\section{Studies on biochemical profiling and bio- fertilizing efficacy of Azolla (Azolla pinnata) and Duckweed (Spirodela polyrhiza)}

\author{
Suyog Aware, Shubham Malode, Bhushan Mahure and Swapnil Pawar
}

DOI: https://doi.org/10.22271/chemi.2020.v8.i3r.9382

\begin{abstract}
Aquatic plants have adapted to reside in water and extensively get used for human benefits. The nutritive value and bio-fertilizing efficiency of Azolla pinnata (Azolla) and Spirodela polyrhiza (Duckweed) were estimated in the present investigation. Both Azolla and Duckweed were observed to be high in nutritive values and rich in protein content, carotenoids, amino acids, anti-oxidants, starch and fibres. However, Azolla pinnata was observed to have prime nutritional qualities than Spirodela polyrhiza. Significant increase in growth of test plants (Vigna unguiculata) in terms of shoot and root length under the treatment with $10 \%$ and $20 \%$ of cellular extracts as compared to control condition confirmed their efficacy as bio-fertilizers even in low concentration of $20 \%$ extract. This study showed that both Azolla pinnata and Spirodela polyrhiza can be useful for quality nutrient supplement for humans as well as animals and can be applied as efficient environment-friendly and economic bio-fertilizers for plant growth.
\end{abstract}

Keywords: Azolla, duckweed, biochemical profiling, nutritive supplement, bio-fertilizer

\section{Introduction}

Azolla pinnata and Spirodela polyrhiza (Duckweed) are aquatic plants, Azolla being a pteridophyte and duckweed an angiosperm ${ }^{[30]}$. In this era, where the world is in continuous and never ending search for cheap and nutritional rich food supplement, these aquatic plants are emerging as a prominent source for nutrition rich supplements as well as for medical and agricultural benefits ${ }^{[11,20]}$. Azolla is commonly referred as "Green Gold Mine" due to its nutrional value. Moreover, it is also known to be useful for biogas production, hydrogen rich fuel, biofertillizer production, water quality improvement, reduction to ammonia volatilization and as a controlling agent for mosquitos and weed ${ }^{[27,72]}$. Several studies on Azolla have shown its great potential of nitrogen fixation in association with Anabena azollae [16]. Furthermore, it can be considered well for human consumption to enrich nutritional requirement for its nutritional value and ease of cultivation ${ }^{[73]}$. While, Duckweed has gained attention of many researchers because of its composition made up of large amount of essential amino acids along with macro and micro elements such as $\mathrm{Ca}$ and $\mathrm{Cl}{ }^{[4,36]}$ with its tolerance to extreme conditions with high growth rate ${ }^{[28]}$. Even consumption of Duckweed is common with the local name 'Khai-Nam' in some regions of Southeast Asia, including Laos, Thailand and Myanmar ${ }^{[14]}$. These two plants are suitable to be used as bio-fertilizer, biofuel, livestock feed, nutrient supplement as useful for $\mathrm{CO}_{2}$ sequestration, waste water treatment, rice

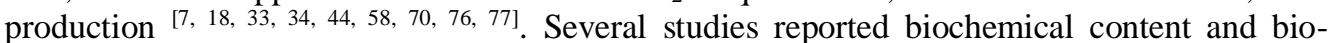
fertilizing efficiency of Azolla and Spirodella. However, biochemical content and biofertilizing efficiency of different species of genus Azolla and Spirodela vary to a wide range. Hence, the present study was undertaken to to estimate the biochemical content of Azolla pinnata and Spirodela polyrhiza as well as effect of their cellular extract on plant growth in order to find their suitability for human/animal feed and bio-fertilizing efficiency.

\section{Material and methods}

\section{Plant material}

$100 \mathrm{gm}$ of Azolla pinnata was collected from K. K. Wagh college of Agricultural Biotechnology, Nashik and $200 \mathrm{gm}$ spirodella polyrhiza was collected from Shri Swami 
Samarth Pradhan Seva Kendra, Dindori, Nashik. Collected samples were subjected to multiplication in a tray with tap water for 25 days. After 25 days, sufficient amount of both plants was harvested for biochemical analysis and remaining plants were kept for multiplication.

\section{Biochemical analysis}

\section{Estimation of total chlorophyll and carotenoid}

Total chlorophyll content of Azolla and Duckweed was estimated according to procedure by Arnon, (1949) ${ }^{[9]}$. Where,
Carotenoid contents were determined using method proposed by Duxbury and Yentach (1956) ${ }^{[24]}$. The absorbance of obtained solution was measured at $663 \mathrm{~nm}$ in the spectrophotometer for total chlorophyll content determination and for carotenoid estimation, pooled out supernatants was subjected to measure absorbance at $450 \mathrm{~nm}$. The total chlorophyll and carotenoid content was calculated using following formula and output expressed in $\mathrm{mg} / \mathrm{ml}$.

Chlorophyll-a mg/gm tissue $=12.7(\mathrm{~A} 663)-2.69(\mathrm{~A} 645) \times \mathrm{V} / 1000 \times \mathrm{W}$

Chlorophyll-b mg/gm tissue $=22.9(\mathrm{~A} 645)-4.65(\mathrm{~A} 663) \times \mathrm{V} / 1000 \mathrm{x} \mathrm{W}$

Total chlorophyll mg/gm tissue $=20.2(\mathrm{~A} 645)+8.02(\mathrm{~A} 663) \times \mathrm{V} / 1000 \times \mathrm{W}$

Carotenoid content $=\mathrm{D} \times \mathrm{V} \times \mathrm{f} \times 10 / 2500$

Where,

A = absorbance at specific wave length

$\mathrm{W}=$ fresh weight of tissue extracted

$\mathrm{V}=$ volume of extract in $\mathrm{ml}$.

$2500=$ average extinction coefficient of pigments

Estimation of total free amino acids and protein

Ninhydrin was utilized for estimation of total free amino acids from Azolla and Duckweed with reference to method of Moore and Stein, (1948) ${ }^{[43]}$. Three replicated trials were performed for each plant and the absorbance of obtained solution was observed at $570 \mathrm{~nm}$ against blank reagent. Outcomes were determined in $\mathrm{mg} / \mathrm{gm}$ of sample.

The protein content of Azolla and Duckweed ground samples were analyzed by method of Lowry et al, (1951) ${ }^{[41]}$. Folin reagent was added in three tubes of both plants containing initial solution and followed by mixing well. Blue color was developed in solutions and these solutions were analyzed in spectrophotometer at $660 \mathrm{~nm}$. Standard graph was prepared with bovine serum albumin and results were expressed in $\mathrm{mg} / \mathrm{ml}$

Estimation of total phenol, starch and cellulose content:

Total phenolic content was estimated using Folin-Ciocalteau reagent for Azolla and Duckweed with the reference to method proposed by Singleton and Rossi in $1965^{[60]}$. Final extract solutions were analyzed in spectrophotometer at $650 \mathrm{~nm}$ against blank reagent and further calculation were made on the basis of standard curve using different concentration of gallic acid as a check and results expressed in $\mathrm{mg} / \mathrm{ml}$. Whereas, Thayumanavan and Sadasivam's, (1982) [68] method was applied to determine starch concentration using anthrone reagent. After addition of anthrone reagent, initial solutions became red and intensity of red solution was measured in spectrophotometer at $630 \mathrm{~nm}$ with blank reagent as standard. Standard graph was prepared for estimation of starch in $\mathrm{mg} / \mathrm{ml}$. Moreover, Cellulose content of both plants was estimated by method of Scott TA and Melvin EH, (1953) ${ }^{[55]}$. At the end of followed method, green color was observed and its intensity was measured at $620 \mathrm{~nm}$ in spectrophotometer against blank reagent. Determination of cellulose concentration was done with standard graph in $\mathrm{mg} / \mathrm{ml}$.

Estimation of acid detergent fibre (ADF) and acid detergent lignin (ADL)

Both ADF and ADL were estimated by procedure reported by Goering HK and Van Soest PJ, (1975) ${ }^{[26]}$. Output of ADF was expressed in percentage $(\%)$ and total percentage of ADF was determined.

\section{Plant growth analysis}

The crop Vigna unguiculata was selected for study on effect of Azolla and Duckweeds biofertillizer extract in plant growth. For preparation of biofertillizer extract, 1 kg of Azolla and Duckweed was boiled with 1 litter of distilled water for 15 minutes and then filtered out. The filtrate was considered as $100 \%$ concentration of the Azolla and Duckweed extract. Furthermore, $10 \%$ and $20 \%$ of extract was prepared from stock extract solution and stored under $0^{\circ} \mathrm{C}-4^{\circ} \mathrm{C}$.

Plant seedlings were supplemented with $10 \%, 20 \%$ of extract and normal tap water as a control. Growth parameters were analysed on 25th day after seed germination. Comparative study was carried out to check individual performance of Azolla extract and Duckweed extract with separate concentration of each, viz. $10 \%$ and $20 \%$.

\section{Results and Discussion}

Azolla (Azolla pinnata) and Duckweed (Spirodela polyrhiza) have several versatile properties which make them suitable for nutritive supplement to humans, animal feeds, bio-fertilizer, biofuel, waste water treatment, bio-indicator, etc. ${ }^{[7,8,14,52]}$. These are easy to grow and have short time period for doubling its biomass which make them suitable candidates for bio-production platforms ${ }^{[64]}$. Because of high nutritional properties, duckweed and Azolla are suitable for feeding a wide range of animals like broiler chicken, goats, sheeps, cattle, rams, buffalo calves, pigs, rabbits, horses, waterfowls, fishes, etc. $[1,6,10,12,17,21,22,23,24,28,29,36,39,52,55,56,60,64,67]$. Many duckweeds and Azolla have been suitable for human consumption as health food supplement $[7,8,53]$. Also, both these organisms have tremendous potential to be used as biofertilizers that enhance various crop plant growths $[29,48,49,61$, $68,71,73,77]$. In the present study, we report the biochemical and nutritive value of Azolla and Duckweed for its suitability as human nutrient supplement and animal feed as well as their suitability to be used as bio-fertilizers for plant growth.

\section{Biochemical and nutritive value of Azolla and Duckweed} The biochemical composition of Azolla and Duckweed was estimated in the present study. Both Azolla and Duckweed were observed to be rich in protein content, carotenoid, amino acids, phenolic antioxidants, starch, cellulose and lignin (Table 1). All these components confirm that these organisms can be good source of complete nutrition for humans and animals. There are many reports regarding the detailed biochemical properties of Azolla and Duckweed $[2,3,5,7,8,10,13$, $17,31,34,37,39,41,44,46,47,58,65,66,78]$. The present investigation 
also corroborates the earlier studies. Both Azolla and Duckweed were observed to be suitable for nutritive supplement. When the nutritive value and quality of both Azolla and Duckweed was compared, Azolla was observed to be better nutrient supplement than Duckweed as it contained more carotenoid, protein, phenolic antioxidants and fibre content.

Table 1: Biochemical Composition of Azolla and Duckweed

\begin{tabular}{|c|c|c|c|}
\hline S. No. & Parameters & Azolla & Duckweed \\
\hline 1 & Chlorophyll content $(\mu \mathrm{g} / \mathrm{g})$ & $156.3 \pm 18.01$ & $140.5 \pm 16.5$ \\
\hline 2 & Carotenoid content $(\mu \mathrm{g} / \mathrm{g})$ & $256.7 \pm 20.3$ & $174.4 \pm 28.1$ \\
\hline 3 & Amino nitrogen content (\%) & $5.804 \pm 1.2$ & $4.858 \pm 0.73$ \\
\hline 4 & Protein content $(\mathrm{mg} / \mathrm{g})$ & $222.78 \pm 19.05$ & $152.46 \pm 11.8$ \\
\hline 5 & Total phenol content $(\mathrm{mg} / \mathrm{g})$ & $73.02 \pm 9.1$ & $70.47 \pm 11.3$ \\
\hline 6 & Starch content $(\%)$ & $4.91 \pm 0.8$ & $3.736 \pm 0.48$ \\
\hline 7 & Cellulose Content (\%) & $8.47 \pm 1.6$ & $8.836 \pm 1.1$ \\
\hline 8 & \multicolumn{3}{|c|}{ Lignin content $(\%)$} \\
\hline & A. Acid Detergent Fibre (ADF) & $38 \pm 5.1$ & $30 \pm 6.3$ \\
\hline & B. Acid Detergent Lignin (ADL) & $19.78 \pm 2.3$ & $1915+36$ \\
\hline
\end{tabular}

\section{Efficiency of Azolla and duckweed as bio-fertilizer}

The effect of Azolla and Duckweeds biofertillizer extract in plant growth was studied using the crop Vigna unguiculata at $10 \%$ and $20 \%$ diluted concentration of original extract $(1 \mathrm{~kg}$ FW/lit). This experiment showed that both Duckweed and Azolla have positive effect on plant growth (Table 2, Figure 1). Shoot length of Vigna plant increased significantly with $10 \%$ and $20 \%$ concentration of both Azolla and Duckweed bio-fertilizer extract as compared to the control (without any supplement), whereas root length increased only in $20 \%$ biofertilizer treatment of Azolla and Duckweed. There was no significant difference in root length under control and $10 \%$ bio-fertilizer treatment of azolla and duckweed. This showed enhanced root growth might not ensure better shoot growth. When impact of different individual concentrations of Azolla extract on shoot and root length were compared, it was

observed that there was statistically significant difference in root length between $10 \%$ and $20 \%$ bio-fertilizer extract, whereas such difference could not be obtained in case of shoot length of Vigna. Interestingly, shoot length under both the treatments with Azolla were significantly more as compared to control. However, in case of duckweed both root and shoot length were significantly different in case of both the treatments.

There are many earlier studies that reported positive impact of various bio-fertilizers including Azolla and Duckweed on

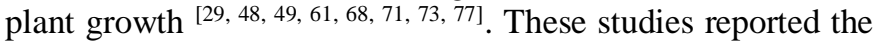
suitability of Azolla as well as Duckweed as bio-fertilizer. Our present investigation also confirms the finding of these earlier reports. In this study, there was an enhancement of shoot and root length upto $40 \%$ ans $71.4 \%$ with $20 \%$ Azolla biofertilizer and 50\% and $42.8 \%$ with Duckweed biofertilzer, respectively (Figure 1B). Hence, it can be inferred that $20 \%$ diluted concentration of original extract (1kg FW/lit) of Azolla and Duckweed are suitable to be used bio-fertilizer for plant growth. The uniqueness of this study is that the diluted Azolla/Duckweed extract from fresh samples worked well at even low concentration i.e. $20 \% 1 \mathrm{~kg} \mathrm{FW/lit} \mathrm{extract.} \mathrm{Also,} \mathrm{the}$ method of preparation that is used in this investigation is very easy and economic that needs no expertise, hence, can be used by any common man for application to their crop field along with irrigation.

Table 2: Effect of Azolla and Duckweed extract on growth of Vigna unguiculate

\begin{tabular}{|c|c|c|}
\hline Treatment & $\begin{array}{c}\text { Root length } \\
(\mathbf{c m})\end{array}$ & $\begin{array}{c}\text { Shoot length } \\
(\mathbf{c m})\end{array}$ \\
\hline Control (No supplement) & $10.5 \pm 1.2$ & $15 \pm 1.8$ \\
\hline Azolla extract 10\% & $11.5 \pm 1.8$ & $18 \pm 3.7$ \\
\hline Azolla extract 20\% & $18 \pm 1.9$ & $21 \pm 3.9$ \\
\hline Duckweed extract 10\% & $11 \pm 1.7$ & $18 \pm 2.2$ \\
\hline Duckweed extract 20\% & $15 \pm 1.6$ & $22.5 \pm 4.3$ \\
\hline
\end{tabular}
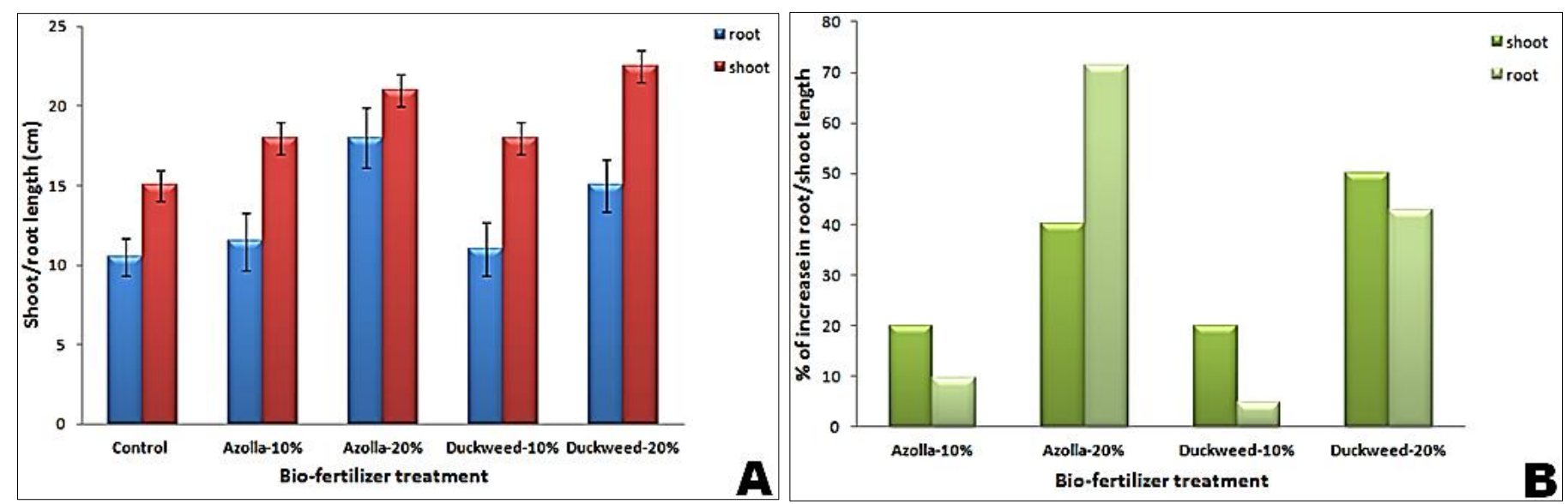

Fig 1: Effect of Azolla and Duckweed bio-fertilizers on growth of Vigna unguiculata in terms of root and shoot length. (A) Root and shoot length of Vigna unguiculata at $10 \%$ and $20 \%$ dilution of original bio-fertilizer extract. (B) Percentage of increase in root and shoot length with bio-fertilizer treatment as compared to control.

\section{Conclusion}

Azolla (Azolla pinnata) and Duckweed (Spirodela polyrhiza) are observed to be high in nutritive values and rich in protein content, carotenoids, amino acids and fibres. These can be useful source for quality nutrients for humans as well as can be used as animal feed. Also, both these organisms are potential, environment friendly and economic bio-fertilizers. The promotion of Azolla and Duckweed cultivation by small farmers and using them as bio-fertilizer in their own fields can be beneficial for developing countries like India.

\section{References}

1. Abdella MM, El-Sayaad GAE, Ghazal FM, El-Baz TA. Sundried Azolla as new feedstuff in growing rabbit diets. Egyptian Journal of Rabbit Science. 1998; 8:81-93.

2. Alalade OA, Iyayi EA. Chemical composition and feeding value of azolla (Azolla pinnata) meal for egg type 
chicks. International Journal Poultry Science. 2006; 5:137-141.

3. Ali MA, Leeson S. Nutritional value and aquatic weeds in the diet of poultry. World's Poultry Science Journal. 1995; 50:239-251.

4. Bartosova A, Maros S, Jozef F. Comprehensive study of duckweed cultivation and growth conditions under controlled eutrophication. Faculty materials sci. tech. trnava. 2015; 23(36):103-107.

5. Anand T, Geetha NP. Azolla as a Biofertilizer in Coffee Plantation. https://ecofriendlycoffee.org/. February 1, 2007.

6. Anitha KC, Rajeshwari YB, Prasanna SB, Shilpa Shree J. Nutritive evaluation of azolla as livestock feed. Journal of Experimental Biology and Agricultural Sciences. 2016; $4: 6$.

7. Appenroth KJ, Sree SK, Bog M, Ecker J, Seeliger C, Bohm V et al. Nutritional value of the duckweed species of the genus Wolffia (Lemnaceae) as human food. Frontiers in chemistry. 2018; 6:483.

8. Appenroth KJ, Sree KS, Bohm V, Hammann S, Vetter $\mathrm{W}$, Leiterer $\mathrm{M}$ et al. Nutritional value of duckweeds (Lemnaceae) as human food. Food Chem. 2017; 217:266273.

9. Arnon DI. Copper enzymes in isolated chloroplasts. Polyphenol oxidase in Beta vulgaris. Plant physiology. 1949; 24(1):1.

10. Balaji K, Jalaludeen A, Richard CR, Peethambaran PA, Senthilkumar S. Effect of dietary inclusion of azolla (Azolla pinnata) on production performance of Broiler chicken. Indian Journal of Poultry Science. 2009; 44:195198.

11. Bandurska K, Berdowska A, Krol M. Transformation of medicinal plants using Agrobacterium tumefaciens (in Polish). Post. Hig. Med. Dosw. 2016; 70:1220-1228.

12. Becerra M, Preston TR, Ogle B. Effect of replacing whole boiled soya beans with azolla in the diets of growing ducks. Livestock Research for Rural Development. 1995; 7:26.

13. Beckingham MKW, Ela SW, Moris JG, Goldman CR. Nutritive value of the Nitrogen-fixing aquatic fern Azolla filiculoides. J. Agri. Food Chem. 1978; 26:1230-1234.

14. Bhanthumnavin K, McGarry MG. Wolffiaarrhiza as a possible source of inexpensive protein. Nature. 1971; 232:495.

15. Bhaskaran SK, Kannapan P. Nutritional composition of four different species of Azolla. European Journal of Experimental Biology. 2015; 5(3):6-12.

16. Bhuvaneshwari K, Singh PK. Response of nitrogenfixing water fern Azolla biofertilization to rice crop. 3 Biotech. 2015; 5:523-529.

17. Bolka PC. Nutritional evaluation of Azolla (Azollapinnata) in broilers and layers. Ph.D. Thesis, Karnataka Veterinary, Animal and Fisheries Sciences University, Bidar, 2011.

18. Bose N. Production and characterization of biodiesel using azollapinnata.Jr. of Industrial Pollution Control. 2018; 34(1):1833-1838.

19. Cheng JJ, Stomp AM. Growing duckweed to recover nutrients from wastewaters and for production of fuel ethanol and animal feed. CLEAN-Soil Air Water. 2009; 37:17-26.

20. Czerpak R, Piotrowska A. Wolffiaarrhiza-the smallest plant with the highest adaptation ability and applications (in Polish). Kosmos. Probl. Nauk Biol. 2005; 54:241-250.
21. Da CT, Lundh T, Lindberg JE. Digestibility of dietary components and amino acids in plant protein feed ingredients in striped catfish (Pangasianodon hypophthalmus) fingerlings. Aquacult.Nutr. 2013; 19:619-628.

22. Dhumal MV, Siddiqui MF, Siddiqui MBA, Avari PE. Performance of broilers fed on different levels of Azolla meal. Indian Journal of Poultry Science. 2009; 44:65-68.

23. Duran AO. Raw palm oil as the energy source in pig fattening diets and Azolla filiculoides as a substitute for soya bean meal. Livestock Research for Rural Development. 1994; 6:2.

24. Duxbury AC, Yentach CS. Plankton pigment monograph. J. Marine Res. 1956; 15:190-191.

25. Ghosh M, Huynh D, Sodhi SS, Sharma N, Kim JH, Kim $\mathrm{N}$ et al. Impact of a novel phytase derived from Aspergillus nidulans and expressed in transgenic Lemna minor on the performance, mineralization in bone and phosphorous excretion in laying hens. Pakistan Vet. J. 2015; 35:360-364.

26. Goering HK, Van Soest PJ. Forage fibres analysis, Dept. of Agriculture, Agricultural research service, washigton, 1975.

27. Golzary A, Tavakoli O, Rezaei Y, Karbassi AR. Wastewater Treatment by AzollaFiliculoides (A Study on Color, Odor, COD, Nitrate, and Phosphate Removal). Pollution. 2018; 4(1):69-76.

28. Goopy JP, Murray PJ. A review on the role of duckweed in nutrient re-clamation and as a source of animal feed. Asian-Australasian Journal of Animal Sciences. 2003; 16(2):297-305.

29. Gualtieri M, Rapaccini S, Balloni W. Effects of the inclusion of Azolla filiculoides meal in feeds for growing rabbits. Rivista di Coniglicoltura. 1988; 25:55-58.

30. Hechler WD, Dawson JO. Factors affecting nitrogen fixation in Azolla caroliniana. Trans Illinois State Acad. Scie. 1995; 88:97-107.

31. Henlus. http://farmersjoint.com/thread-49.html. June 13. 2014.

32. Ismail M. Chemical characterization of protein concentrates of duckweed (family Lemnaceae). Pertanika J. Sci. and Tech. 1998; 6:7-21.

33. Kamalasanana P, Premalatha S, Rajamony S. Azolla - A sustainable feed substitute for livestock. Leisa India, 2002, 15-17.

34. Kannaiyan S, Kumar K. Azolla Biofertilizer for Sustainable Rice Production. Daya Publishing House, Delhi, India, 2005.

35. Khatun A, Ali MA, Dingle JG. Utilization of Azolla (Azolla pinnata) in the diets of laying hen. Anim. Feed Sci. Technol. 1999; 8(1):43-56.

36. Landolt E, Kandeler R. Biosystematics investigations in the family of Duckweeds (Lamnaceae). Veroff. Geobot. Institute. ETH. Zurich. 1987; 2:42-43.

37. Landolt E. Biosystematic investigations in the family of duckweeds (Lemnaceae), volume 2. The family of Lemnaceaea monographic study, vol 1, Vero“ffentlichungen des Geobotanischen Institutes der ETH, Stiftung Rubel, in Zurich (71 Heft), 1986.

38. Lehman W, Silk WK, Knight AW. Protein and nitrate content of Lemnasp. As a function of developmental stage and incubation temperature. Plant Physiol, 1981; 68(1):127-132.

39. Leterme P, Londono AM, Ordonez DC, Rosales A, Estrada F, Bindelle $\mathrm{J}$ et al. Nutritive value and intake of 
aquatic ferns (Azolla fillicoides Lam. and Salvinia molesta Mitchell) in sows. Animal Feed Science and Technology. 2010; 155:55-64.

40. Lipstein B, Hurwitz S. The nutritional value of algae for poultry. Brit. Poult. Sci. 1980; 21:9-21.

41. Lowry OH, Rosebrough NJ, Farr AL, Randall RJ. J. Biol. Chem. 1951; 193:265.

42. Mandal RN, Pandey BK, Chattopadhyay DN, Mukhopadhyay PK. Azolla - an aquatic fern of significance to small-scale aquaculture. Aquaculture Asia. 2012; 17(1):35-36.

43. Moore S, Stein WH. Photometric methods for use in the chromatography of amino acids. J Bio Chem. 1948; 176:367-388.

44. Muradov N, Fidalgo B, Guja AC, Garceau N, T-Raissi A. Production and characterization of Lemna minor bio-char and its catalytic application for biogasreforming. Bioresour.Technol. 2012; 42:123-131.

45. Muztar AJ, Slinger SJ, Burton JH. Nutritive value of aquatic plants for chicks. Poultry Sci. 1976; 55(5):1917-1921.

46. Nam JH, Jung HW, Chin YW, Yang WM, Bae HS, Kim WK. Spirodela polyrhiza extract modulates the activation of atopic dermatitis-related ion channels, Orai1 and TRPV3 and inhibits mast cell degranulation. Journal of pharmaceutical biology. 2017; 55:1324-1329.

47. Parnerkar S, Patel JM, Bhagoji GP, Patel AP, Dave FD. Voluntary intake and nutritive value of the sun dried water fern Azolla pinnata in sheep. Indian J. Anim. Nutr. 1986; 3910:37-39.

48. Parthasarathy R, Kadrivel R, Kathaperumal V. Chemical evaluation of Azolla as a poultry feed ingredient. Indian Vet. J. 2001; 79:144-146.

49. Peters GA, Meeks JC. The Azolla-Anabaena symbiosis: basic biology. Annu. Rev. Plant Physiol. Plant Mol. Biol. 1989; 4:193-210.

50. Rejmankova E. The role of duckweed (Lemnaceae) in small wetland waterbodies of Czechslovakia. In: Wetland ecology and management, 1982.

51. Roy DC, Pakhira MC, Roy M. Estimation of Amino Acids, Minerals and Other Chemical Compositions of Azolla. Advances in Life Sciences. 2016; 5(7):26922695.

52. Rusoff LL, Blakeney EW, Culley DD. Duckweeds (Lemnaceae family): a potential source of protein and amino acids. J. Agric. Food Chem. 1980; 28:848-850.

53. Sadek MF, Fatma, Ahmed G, Hanan AM, Hassanein, Marvat M, Arafa, Elham M. Using of Azolla silage in growing rabbits feeding. Egyptian Journal of Rabbit Science. 2010; 20:67-82.

54. Saengthongpinit W. Indigenous cuisine with a modern flare. Duckweed Forum. 2017; 5:8.

55. Scott TA, Melvin EH. Determination of dextran with anthrone. Anal Chem. 1953; 25(11):1656-1661.3.

56. Shammout MW, Zakaria H. Water lentils (duckweed) in Jordan irrigation ponds as a natural water bioremediation agent and protein source for broilers. Ecol. Eng. 2015; 83:71-77.

57. Sharma JG, Kumar A, Saini D, Targay NL, Khangembam BK, Chakrabarti R. In vitro digestibility study of some plant protein sources as aquafeed for carps Labeorohita and Cyprinuscarpio using pH-Stat method. Indian J. Exp. Biol. 2016; 54:606-611.
58. Shiomi N, Kitoh S. Azolla in a pond, nutrient composition, and use as fish food. Soil Sci, Plant Nutr. 2001; 47(1):27-34.

59. Singh PK, Subudhi BPR. Utilization of Azolla in poultry feed. Indian Farming. 1978; 27:37-39.

60. Singleton VL, Rossi JA. Colorimetry of total phenolics with phosphomolybdic-phosphotungstic acid reagents, The American Journal of Enology and Viticulture. 1965; 16:144-158.

61. Skillicorn P, Spira W, Journey W. Duckweed Aquaculture - A New Aquatic Farming System for Developing Countries, The World Bank. Washington DC, 1993, 76,

62. So ML. Growth characteristics of duck weed and their potential ise as organic fertilizers in Hong Kong. Mangolia Publishing Inc, 1987, 755-762.

63. Sreemannarayana O, Ramachamdraiah K, Sudarshan KM, Ramanaiah NV, Ramaprasad J. Utilization of azolla as rabbit feed. Indian Veterinary Journal. 1993; 70:285286.

64. Stomp AM. The duckweeds: A valuable plant for biomanufacturing. Biotech. Annual Rev. 2005; 11:69-99.

65. Suppadit T, Jaturasitha S, Sunthorn N, Poungsuk P. Dietary Wolffiaarrhiza meal as a substitute for soybean meal: its effects on the productive performance and egg quality of laying Japanese quails. Tropical Animal Health and Production. 2012; 44(7):1479-1486.

66. Taklimi S. Utilization of Azollamicrophyllain broiler feeding. MSc. Thesis, University of Agricultural Sciences, Bangalore (India), 1990.

67. Tamang Y, Samanta G, Chakraborty N, Mondal L. Nutritive value of Azolla (Azollapinnata) and its potentiality of feeding in goats. Environment and Ecology. 1993; 10:755-756.

68. Thayumanavan B, Sadasivam N, Ohtsobo K. Physiochemical basis for the prefunctional uses of certain rice varieties. Qual. Plant. Plant Foods Hum. Nutr. 1982; $34: 253$.

69. Tung HF, Shen RC. Studies of the Azolla pinnataAnabaena azollae symbiosis: Concurrent growth of Azolla with rice. Aquatic Bot. 1985; 22:145-152.

70. Umali LJ, Duncan JR, Burgess JE. Performance of dead Azolla filiculoides biomass in bioabsorption of $\mathrm{Au}$ from wastewater. Biotechnology Letters. 2006; 28:45-49.

71. Van Soest PJ, Robertson JB, Lewis BA. Methods for dietary fiber, neutral detergent fiber, and nonstarch polysaccharides in relation to animal nutrition. Symposium: Carbohydrate methodology, metabolism and nutritional implications in dairy cattle, 1991.

72. Wagner GM. Azolla: a review of its biology and utilization. Bot Rev. 1997; 63:1-21.

73. Waseem R, Preeti R, Suchit AJ, Pramod WR. Impacts of endosulphan on the growth and pigment contents of macrophyte Azolla myriophyllum. Journal of Stress Physiology \& Biochemistry. 2012; 8(4):98-109.

74. Watanabe I. Use of symbiotic and flee-living blue-green algae in rice culture. Outlook on Agric. 1984; 13:166172.

75. Wittouck P, Detimmerman F, Petry M, Hove C, Van. Azolla as a food for rabbit in Africa. Journal of Applied Rabbit Research. 1992; 5:1058-1062.

76. Xu J, Zhao H, Stomp AM, Cheng JJ. The production of duckweed as a source of biofuels. Biofuels. 2012; 3(5):589-601. 
77. Yadav V, Mehra B, James A. Industrial wastewater treatment using Spirodela polyrhiza. Journal of pharmacognosy and phytochemistry. 2017; 6(4):892-895.

78. Yao Y, Zhang M, Tian Y, Zhao M, Zhang B, Zhao M et al. Duckweed (spirogyra polyrhiza) as a green manure for increasing yield and reducing nitrogen loss in rice production. Field crop research. 2017; 214:273-282.

79. Yu G, Liu H, Venkateshan K, Yan S, Cheng J, Sun XS et al. Functional, physiochemical, and rheological properties of duckweed (spirodela polyrhiza) protein. American Society of Agricultural and Biological Engineers. 2011; 54(2):555-561.

80. Ziegler P, Sree KS, Appenroth KJ. Duckweeds for water remediation and toxicity testing. Toxicol. Environ. Chem. 2016; 98:1127-1154. 